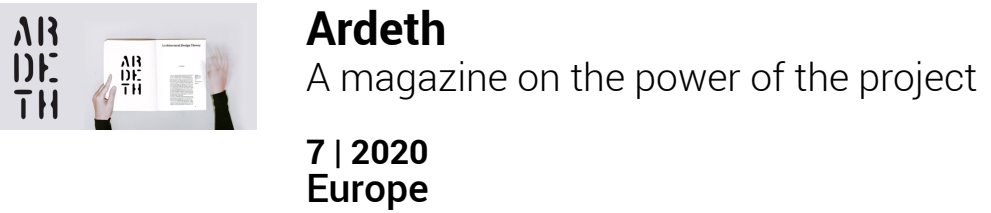

\title{
Vu' cumprà
}

Acting on the Margins of the European Project

\section{Peter Volgger}

\section{(2) OpenEdition}

\section{Journals}

Electronic version

URL: https://journals.openedition.org/ardeth/1953

ISSN: 2611-934X

\section{Publisher}

Rosenberg \& Sellier

\section{Printed version}

Date of publication: 1 December 2020

Number of pages: 157-175

ISSN: 2532-6457

Electronic reference

Peter Volgger, "Vu' cumprà", Ardeth [Online], 7 | 2020, Online since 01 June 2021, connection on 21

September 2021. URL: http://journals.openedition.org/ardeth/1953 


\section{Vu' cumprà. \\ Acting on the Margins of the European Project}

Peter Volgger

Abstract

In the past decades, the status of territories and everyday urban experiences has been strongly bound with notions of globalisation and migration. In this critical discussion, the effects of migration are identified according to multiple dimensions in order to generate knowledge on 'space in transition' by exploring how Senegalese traders who belong to the Mouride brotherhood make claims on and use space during their time in Italy. 'Mourides' are groups with very high mobility and exemplify 'transmigrants'; they establish 'circulatory territories' by commuting between their land of origin and the host country - changing their whereabouts seasonally. At the architectural level, the key question raised by migration is how diversity can be acknowledged, valued, and accommodated by the built environment.
Affiliatio

Innsbruck

University, Institute for Architecture Theory and History of Architecture

Contacts: peter [dot] volgger [at] uibk [dot] ac [dot] at

Received: 28 October 2020

Accepted: 19 January 2021

DOI:

10.17454/ARDETH07.10

ARDETH \#07 
The implications of migration are drastically changing our understanding of urbanism, a field traditionally limited to the architectural scale of the city.
Fictional urbanism

Deterritorialized conditions created by migrants have led to an urbanism of artificial reterritorialization that may be called a 'fictional urbanism', being based on fragile mental constructions that are manifested in an archipelago of fragments, each of which establishes its own space and rules, provoking the European political centre (Clifford, 1998: 369). With respect to migration, the last few years have been characterised by reactionary policies and the outburst of populist discourses, the raising of fences, new border closures, and political division within the European Union (EU). Spaces within the EU and Schengen Zone promote what Alain Balibar in Europe as Borderland has called "translation" and a variety of encounters that can potentially engender transnational hybridity and new, flexible notions of identity (Balibar, 2009).

The implications of migration are drastically changing our understanding of urbanism, a field traditionally limited to the architectural scale of the city. Liminal spaces offer a new perspective on how space can be constructed and occupied. From now on, we will have to study architecture and urbanism on different scales and investigate the new territories that are emerging at their intersections. Recent literature deals with this abundantly: David Harvey's "time-space-compression” is one key to the level of transnationalism we are experiencing today. Both Saskia Sassen and Doreen Massey claim that the penetration of new production technologies into the developing world disrupts customary livelihoods and traditional work structures. Peggy Levitt describes "heightened global economic interconnectedness" as the intensified circulation of global media and commodities while Arjun Appadurai (1996) calls deterritorialized spaces “scapes”. Architects have to deal with migration as well. Alejandro Aravena's Venice Biennale (2016) included architects "Reporting from the Front" in battles against migration-related challenges, among other issues. In USE, Uncertain States of Europe, Stefano Boeri shifted the emphasis from types to territories in which, as in a kind of Petri dish, spatial mutations take place on the basis of societal changes. Paul Virilio's artistic work with architects Diller and Scofidio, Exit, explored global migration, translating statistics into graphic representation. Teddy Cruz and Fonna 
Forman have pushed migration to the centre stage within the architectural community. Diego Barajas investigated how migrants of the Cape Verde Islands have reproduced their natural archipelago in Rotterdam (Barajas, 2003): they connect one "urban island" with the other through public transport, just like they did at home using their boats. By constantly adapting to new circumstances and creatively reassembling existing resources, migrants open up new perspectives on the local effects of worldwide dynamics.

Hence, this essay pleads for an expanded understanding of "architecture to come". Multiple identities and cross-border networks of migrant communities put our prior assumptions to the test as regards the nation state's functioning as a stable and self-contained space (Glick Schiller et al., 1992; Pries, 1999); they also challenge our belief that architects can shape spatial practices. Today's progressive discourses on urbanisation favour new territories, yet perhaps without nostalgia for any loss, in a world which is increasingly inhabited by nomadic actors flowing across networks and, as Saskia Sassen puts it, becoming "local villagers within the global cities of the world" (Sassen, 2004: 553).

Dealing with migration might involve challenging contemporary conversations to shift away from notions of inclusion towards the anti-political project of unmaking a world that casts homeless people as problems for the nation state. In order to cope with territories of dispersion and alienation, we have to find new means and strategies. The key to finding these is hidden in the way people, without waiting for architects, are organising themselves.

\section{Mouride space-making}

This essay focuses on migration and its local effects on medium-sized cities in northern Italy, summarising some of the results of a research project carried out by the Institute for Architectural Theory of the University of Innsbruck between 2012 and 2015 in Bolzano, Duna Verde, Zingonia, and Porto Recanati. We found that the history of the 'Muridiyyah' offers a paradigmatic model for studying the impact of migration on the European territory. 'Mourides' from Senegal belong to diasporic communities that operate within an in-between-space through direct relationships between the global and the personal. As one Mouride

\section{The history of the 'Muridiyyah' offers a paradigmatic model for studying the impact of migration on the European territory.}




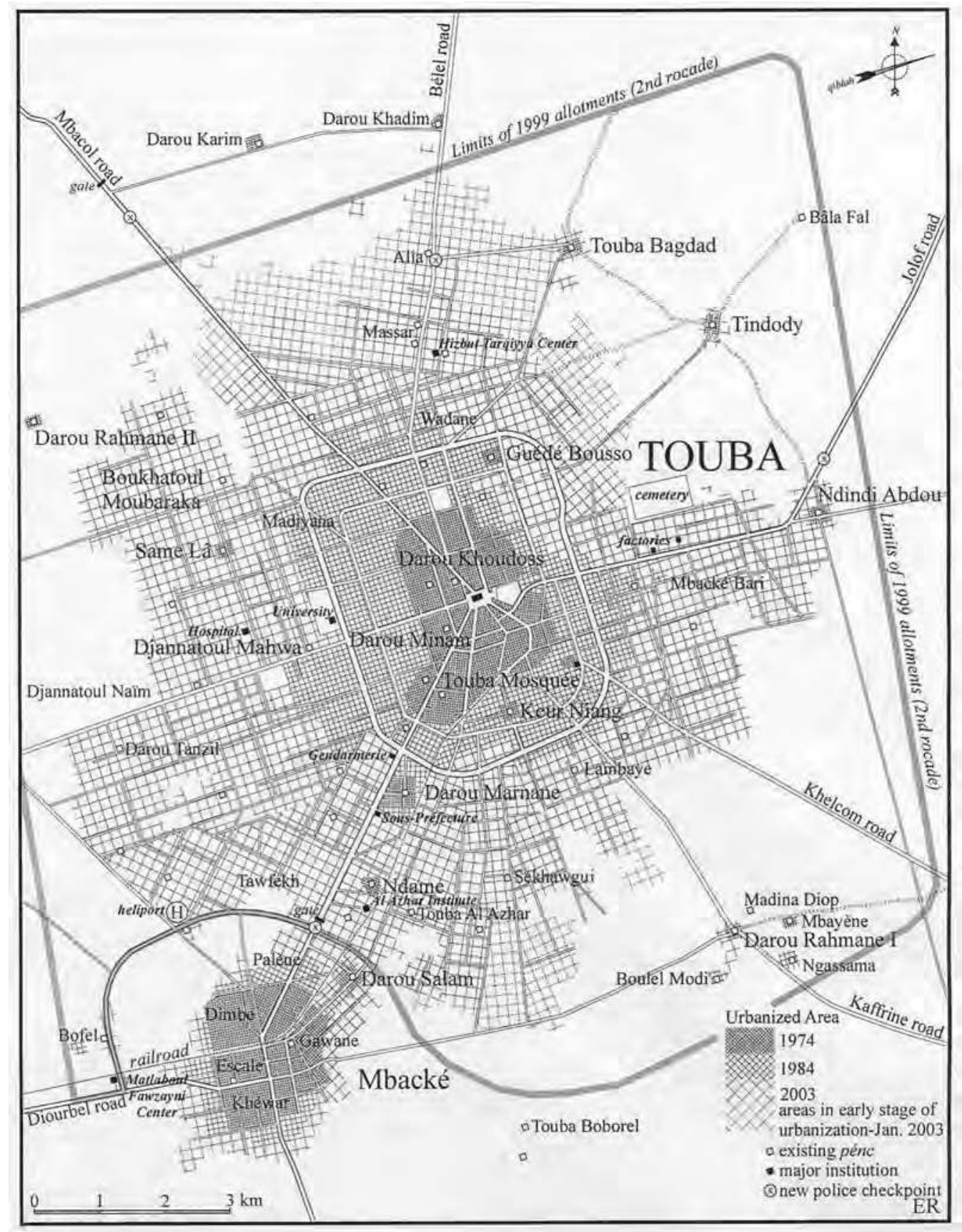

Fig. 1 - Map of Touba. Courtesy of Eric Ross. put it: "Our homeland is built on sand, and, like the sand, we are blown everywhere!" (Ebin, 1996: 96). For the Mourides, "being mobile" is not an exception but rather a "way of life". Interestingly, the idea of leaving is rooted in their agenda as one way of following one's 
submission to the religious path, inasmuch as "mobility is engrained in the history, daily life and experiences of the population” (De Bruijn et al., 2001: 1).

Transmigrants neither belong to their country of departure nor to the country of arrival (Grillo, 2000): they constantly move and stay with members of their group, consuming Senegalese satellite channels and "Radio Touba" only. They inhabit a space that exists not in one time but in many, at the intersection of other spaces and in juxtaposition with them.

The Mouride brotherhood, who seceded from West African Sufism (Schmidt di Friedberg, 1994), was founded by Ahmadou Bamba in rural Senegal in the late nineteenth century; ever since, it has experienced a steady process of transformation. The Muridiyyah have remained active in the holy city of Touba while becoming a global phenomenon. The Mourides scattered around the world long to visit Touba, self-defined 'capital' of the Mouride Sufi order, which is increasingly thriving on its global connectedness. The diffusion of the 'Touba' toponym through names of expatriate associations and institutions reflects its status as a global city. Touba is the only place where worldwide Mouride networks materialise. It has grown exponentially and is now Senegal's second city, with an estimated population of one million.

In the mid-1980s, Mouride immigrants were nicknamed 'vu' cumprà?' (a malapropism of vuoi compra$r e$ ?) in Italy. They were itinerant traders and nearly full-time travellers establishing 'circulatory territories’ (Tarrius, 1994), constantly moving in search of new goods and clients. They had neither the time nor resources to transform their living quarters in any radical way. Groups are organised on the basis of 'moving households'. Multiple ties - such as place of origin, friendship, kinship, and religion - create a closely-knit structure (Ebin, 1995: 328). In accordance with their religious beliefs, they work in order to cede their income to their spiritual leader. The 'marabout' (Mouride cleric) consecrates their 'talibes' and advises them in hard times.

On Italy's beaches, the Mouride tradesman will sell nearly everything, but for practical reasons most of them specialise in fake ware (e.g., Asian-made watches, fantasy jewellery, sunglasses, umbrellas, and other

\section{Mouride were itinerant traders and nearly full- time travellers establishing 'circulatory territories' constantly moving in search of new goods and clients.}




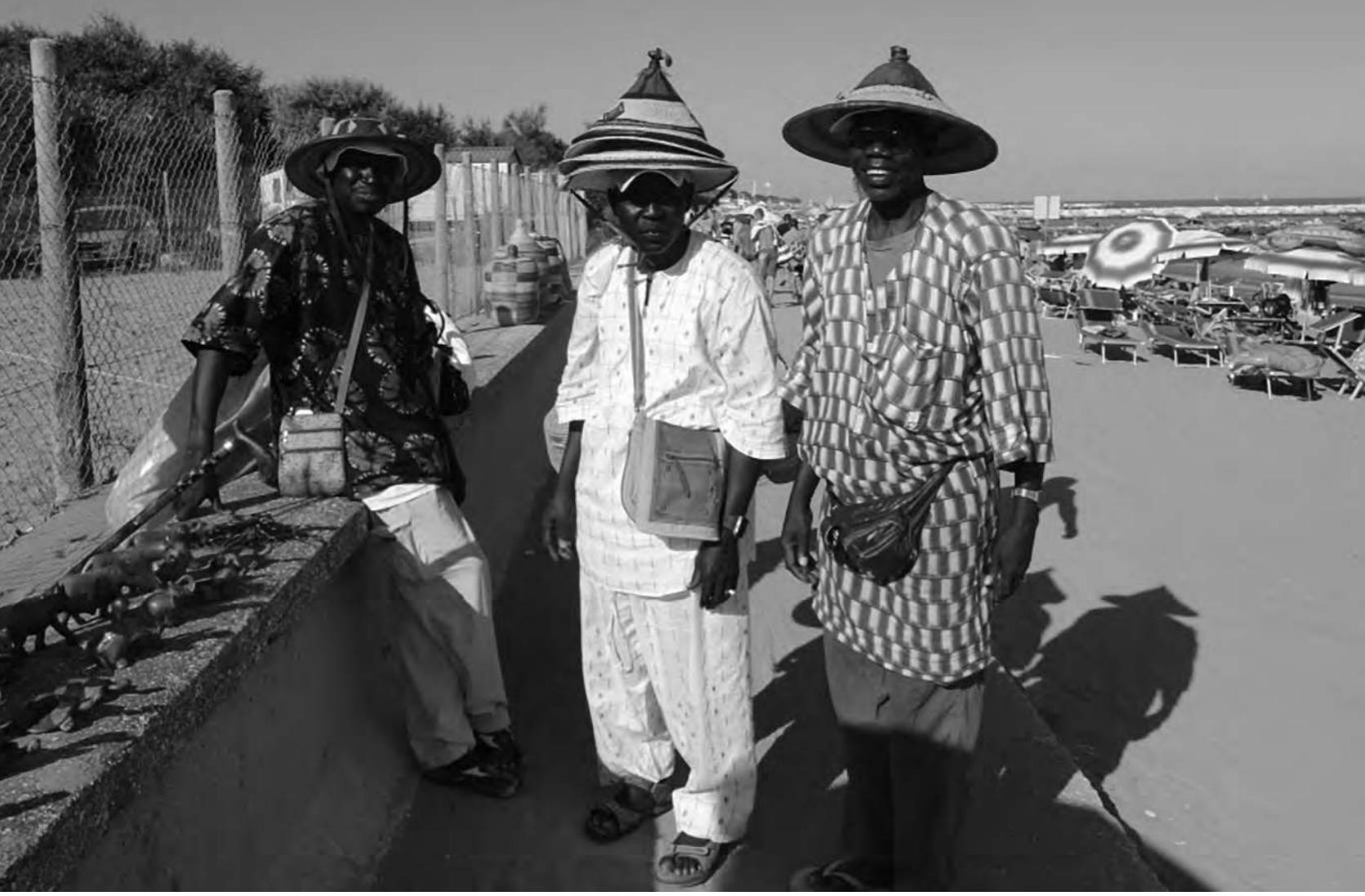

Fig. 2 - Mourides in

Duna Verde.

Courtesy of the author.

\section{As patterns of dispersion intensify, they not only generate fragmented societies, but also a new territorial cohesion.}

small items). While this occupation opened a way for the Mourides to survive, it is an arduous life even today. Nevertheless, about 70,000 Senegalese people are officially registered in Italy, over $90 \%$ of them Mourides. During the 1980s, most Mourides did not question the temporary nature of their time in Italy (Riccio, 1999). Various national policy frameworks, unable to address their transnational livelihood, confronted the Mourides with ever shifting socio-political conditions. In a second phase, Mouride workers achieved a measure of stable economic integration through employment in local industries. All the same, their life in Italy is neither a case of integration nor exclusion, but something new and different.

\section{The Mouride Archipelago}

As patterns of dispersion intensify, they not only generate fragmented societies, but also a new territorial cohesion. Migrants make the host countries their own. 
Hence, the term 'niche' and the notion of 'reterritorialization' go beyond economic activity, although this is their raison d'etre. The social infrastructure allows Mourides to detach themselves from their country of origin without actually cutting the umbilical cord and produce a new collective sphere in "so-and-so's land". Two spaces emerge, as Mahamet Timera (2014: 42) writes: The 'interior' (the country), and the 'exterior': the archipelago of niches that migrants create for themselves; these two spaces intersect and sometimes blend into one another.

Migration theory has long been aware that transformation is always, first and foremost, a matter of survival. Comprehending architecture as something global that includes both the material and immaterial qualities of space is of paramount importance to its evolution, survival, and endurance as a meaningful tool of transformation.

The Mouride territorial organisation presents alternative options for publicness and for a discourse on re-addressing relations in terms of a conception of architecture without architects that transforms 'non-places' (Marc Augé) into ‘places'. Because the grounding of one's action within the polity concerns not just the body, but the social body as well, Mourides connect different places to 'trans-localities'
Fig. 3 - The Mouride Territory. Courtesy of the author.
Mourides connect different places to 'trans-localities' acting on more than one place simultaneously.

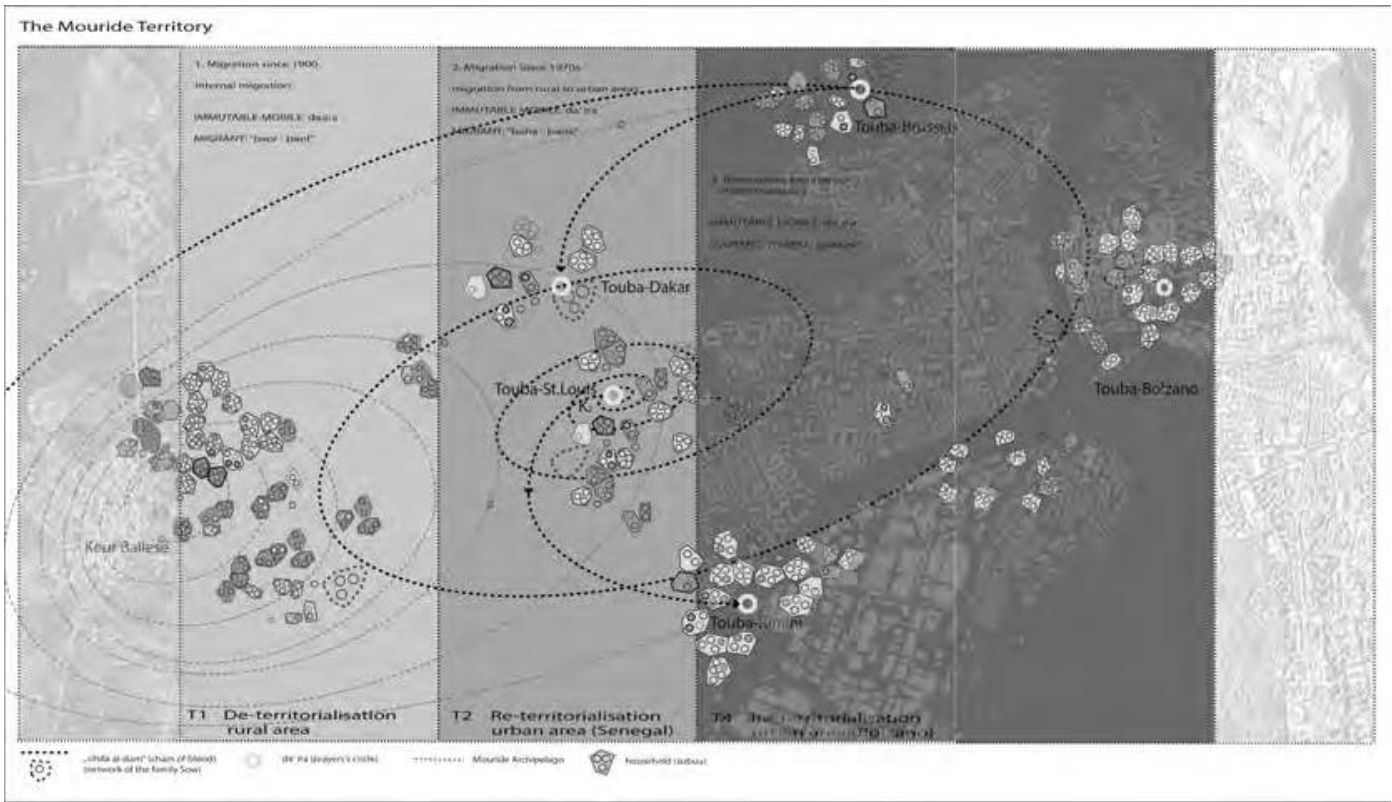




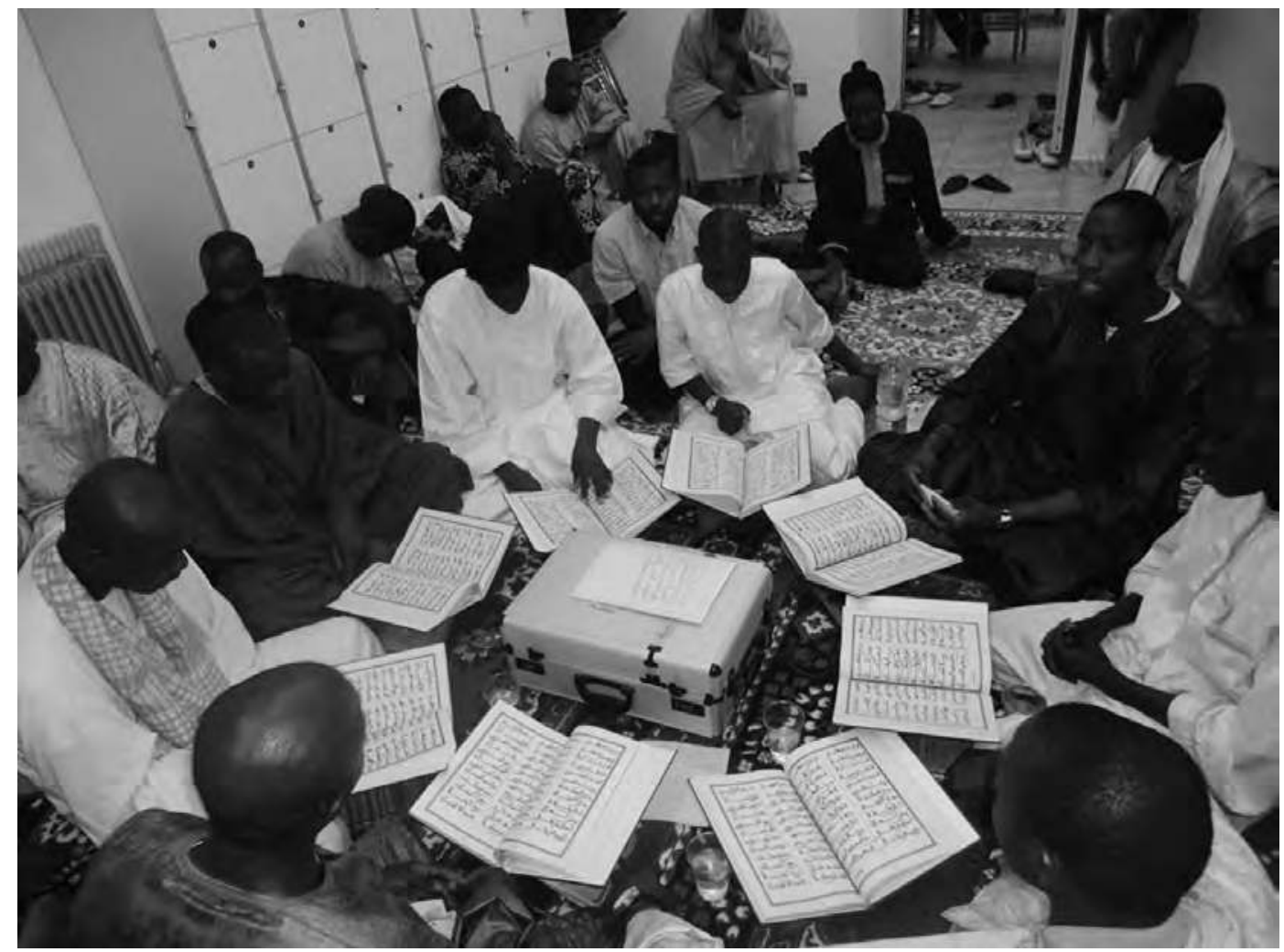

Fig. 4 - Da'ira in

Bolzano. Courtesy of the author. (silsila al-baraka) acting on more than one place simultaneously (Sinatti, 1006). They intertwine procedures from the land of origin with the current host country into a multi-local space. This complex connection of places works like a navigation tool ('flying scaffolds') in a foreign environment, turning ritual performance (speeches, prayers, or gatherings) into a new logic.

The Mouride archipelago can be investigated by observing its economic cycles and structures (silsila al-dam). Many travelling vendors currently living in Italy were tradesmen in Senegal and hence are still connected to their home country through their trading network. It is worth noting that, unlike a network, an archipelago always has a centre. To understand Mouride trading practice, we have to realise that it is an instrument for mutual support.

Before going any further, it is important to make a distinction between 'migrating space' and 'space of migration'. The latter is the space occupied by migrants and 
marginalised people, whereas 'migrating space' resists the use of architecture as a tool of oppression and reappropriates space as a tool for transformation. It proposes a subversion of the norm and a rupture in the social fabric. Because of this, any 'migrating architecture' must remain firmly anchored in migration and its radical roots, and be considered an 'an-architecture', that is to say, an architecture born of necessity and creativity that uses insignificant, liminal, and transient spaces.

Appadurai's 'production of locality' (Appadurai, 1995) can be used to show how Mourides build an autonomous layer - an 'African village' - within a given urban context. This African layer can be interpreted as an economic and spatial reconfiguration of Mouride territory. 'Home' can be both the physical place (the 'domestic household') and the symbolic 'space of belonging' to local, national or transnational communities within which people regard themselves as 'being at home'. Yet how can the Mourides maintain their identity over long periods of time and distances, while also adapting to changing local conditions? This question can be answered by referring to a topological model. Under a simple, common definition, topology is the study of properties that remain invariant under deformation. All in all, the present interest in topological theory within architectural discourse merely results in piecing together dispersed settlement patterns. Similarly, the way in which transmigration space is accounted for in the dominant discourse is far too incomplete and static (in fact, trying to represent anything through a single model is preposterous). For Mouride space is constantly shifting, moving, evolving, thus reinforcing the profound disconnect between architecture and the space it occupies. As their setting shifted to a trans-urban one, Mourides brought along all their African itinerant trade practices, which are linked to the notion of 'circulating territories' (Tarrius, 1994).

In reality, the physical space in which Mouride places exist becomes secondary. What gives them a universality and a capacity to be reproduced anywhere and anytime are the Mouride people inhabiting them. As such, liminal spaces of Mouride migration are both unique and generic in nature. The Mourides have turned their culture into cocoons, while rooting these in, or transporting them to times and places in

\section{'Home' can be both the physical place and the symbolic 'space of belonging' to local, national or transnational communities.}


Fig. 5 - The Mouride Archipelago.

Courtesy of the author. which they felt they had a place. Their networks are composed of only two elements, which are constantly connected according to given rules: the 'mutable mobiles' (households) and 'immutable mobiles' (da'ira).

\section{Making room versus creating space}

The first building block of Mouride networks, households (in Wolof: subuu), consists of groups of three or four persons and are positioned along migrational trajectories for strategic reasons. Their need for secrecy is deeply rooted in history: as a matter of survival, Mouride households needed to be adaptable, ephemeral, and anonymous. Mouride rooms are often perceived as weaving together elements that create impermanent frameworks for daily life and special events alike. For instance, the focus group in Bolzano was held in the kitchen area of a small apartment shared by Mamadou and Bayal, both working at car factories nearby. The apartment was tidy and sparsely decorated - a small picture of the religious leader was the only adornment on the white walls. Many migrant factory workers whom we interviewed in Italy reported little pleasure in their domestic life abroad. Few put much effort into decorating their spaces, choosing instead to spend that money and energy on living spaces in Senegal, either building or maintaining their own homes there.
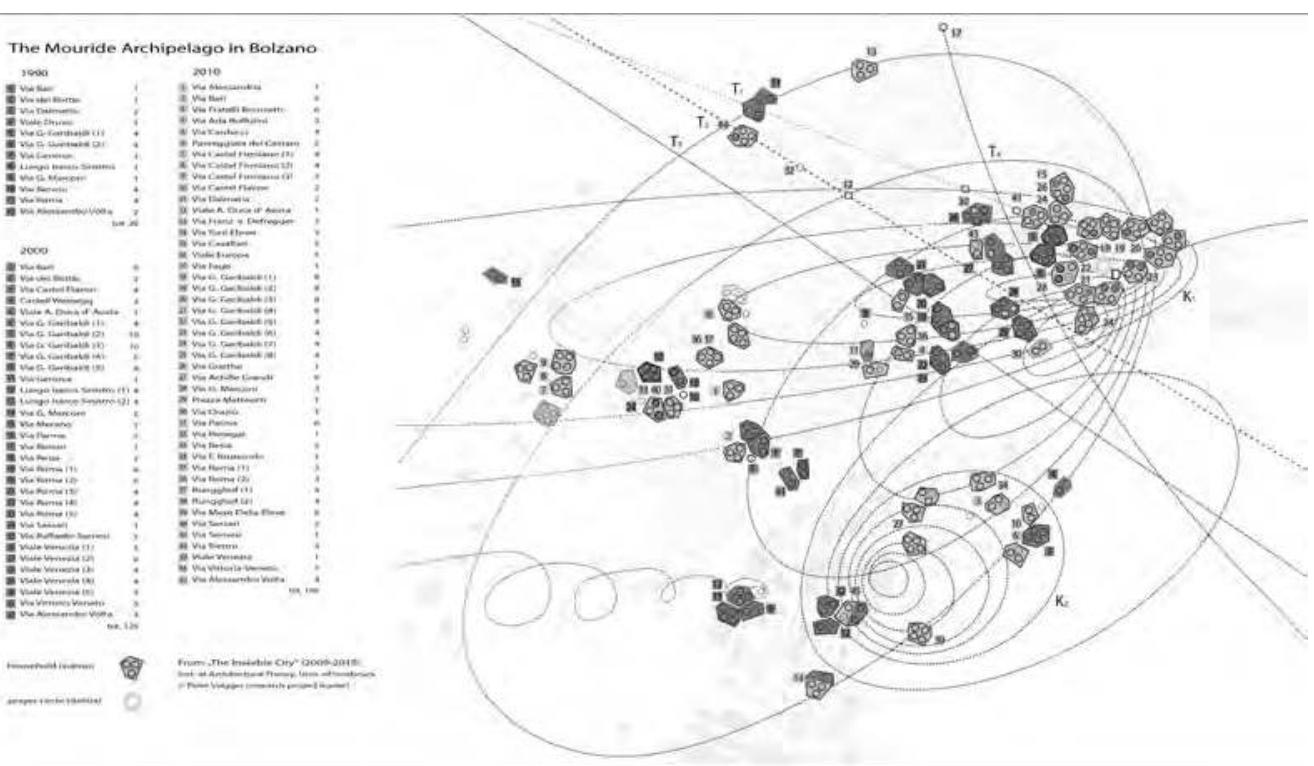
Indeed, no matter how strongly architects believe in the home as a 'machine for living', people - rather than architects - modify their environments accordingly.

Not only do the Mourides have different ideas about what a 'home' should be like, they may have more than one place they call home. Their more diffuse notion of family generates a wider range of places where to feel 'at home'. A Mouride may sleep, eat, drink tea, watch Touba TV, and spend time in different households; like any group of migrants, abroad the Mourides tend to stick together, creating a place of belonging and warmth that excludes the outside world.

For the Mourides in Duna Verda, home for most of the year is a series of hotel rooms. There, they have taken over a few residential hotels (more like boarding houses). Sleeping two to a bed, the room population is far above whatever the hotel initially intended. The Mourides in Bolzano and Zingonia live in groups in cheap apartments. Hotel space becomes differentiated according to Mouride needs: certain rooms are designated as kitchens, large rooms are meeting places. The capacity to adapt and change with minimal means constitutes a central aspect of Mouride space-making. The only constant is a black and white photograph of Ahmadou Bamba, which hangs in every apartment. The second building block of Mouride networks is the da'ira (urban prayer circle). Some marabouts have many of these scattered around the world and generally visit them once a year to collect gifts and money. The da'ira facilitates the operation of dispersed territories, acting as an interface between here and there; inside, it is undeniably more Touba than Bolzano. Mouride migrants take care of its decoration and its overall atmosphere in order to guarantee an immersive experience.

An analysis of the da'ira from a different perspective reveals that they are not marginal aberrations, but sophisticated urban models of increased mobility. The da'ira is an 'architecture of dispersion' that reveals the close, often intimate links between informal and spontaneous phenomena and the all-absorbing collective space of the brotherhood - in which globalised bodies are immersed and with which, with each visit, they increasingly become familiarised. The effects generated by the artificial environment of the da'ira on the subjects also produce a transformation.

\section{No matter how strongly architects believe in the home as a 'machine for living', people - rather than architects - modify their environments accordingly.}

The da'ira is an 'architecture of dispersion' that reveals the close, often intimate links between informal and spontaneous phenomena and the all-absorbing collective space of the brotherhood. 


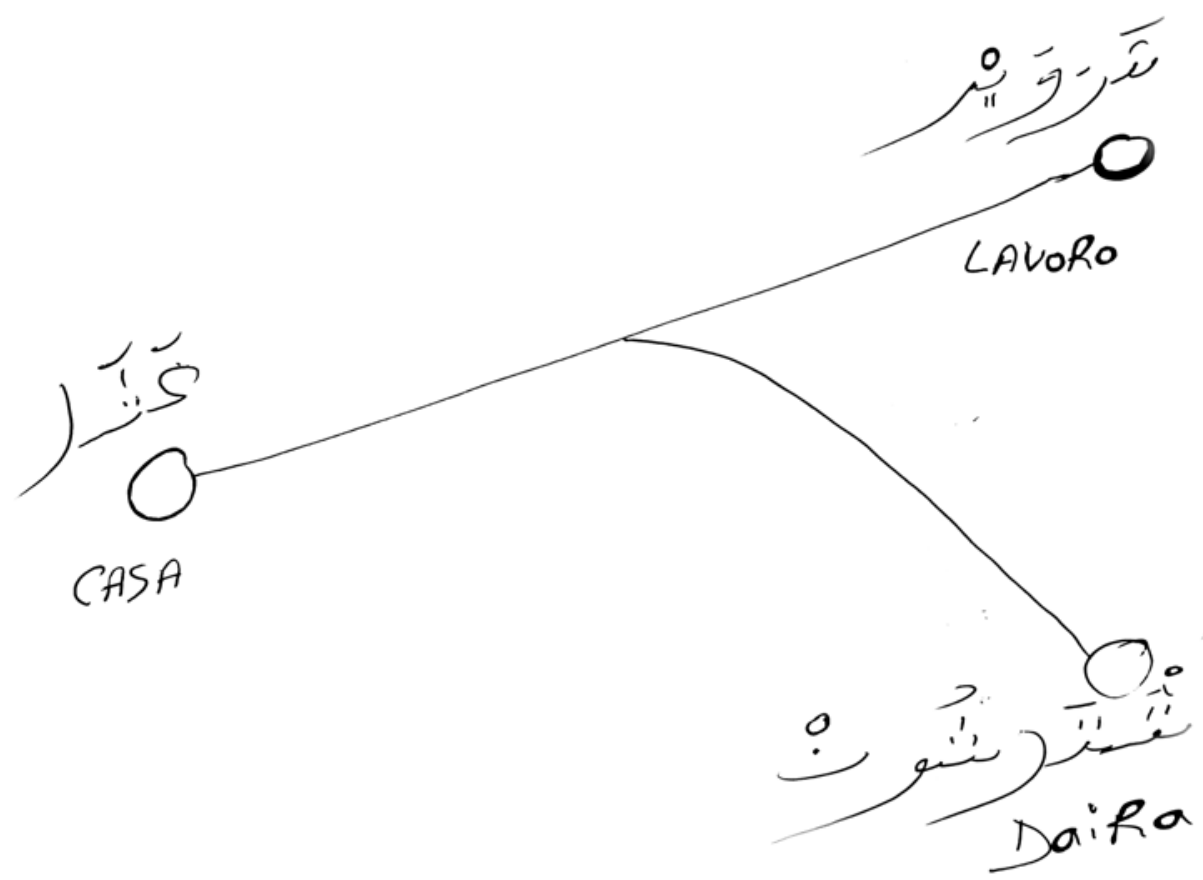

Fig. 6 - Bayal's Mobility Map. Courtesy of the author. 


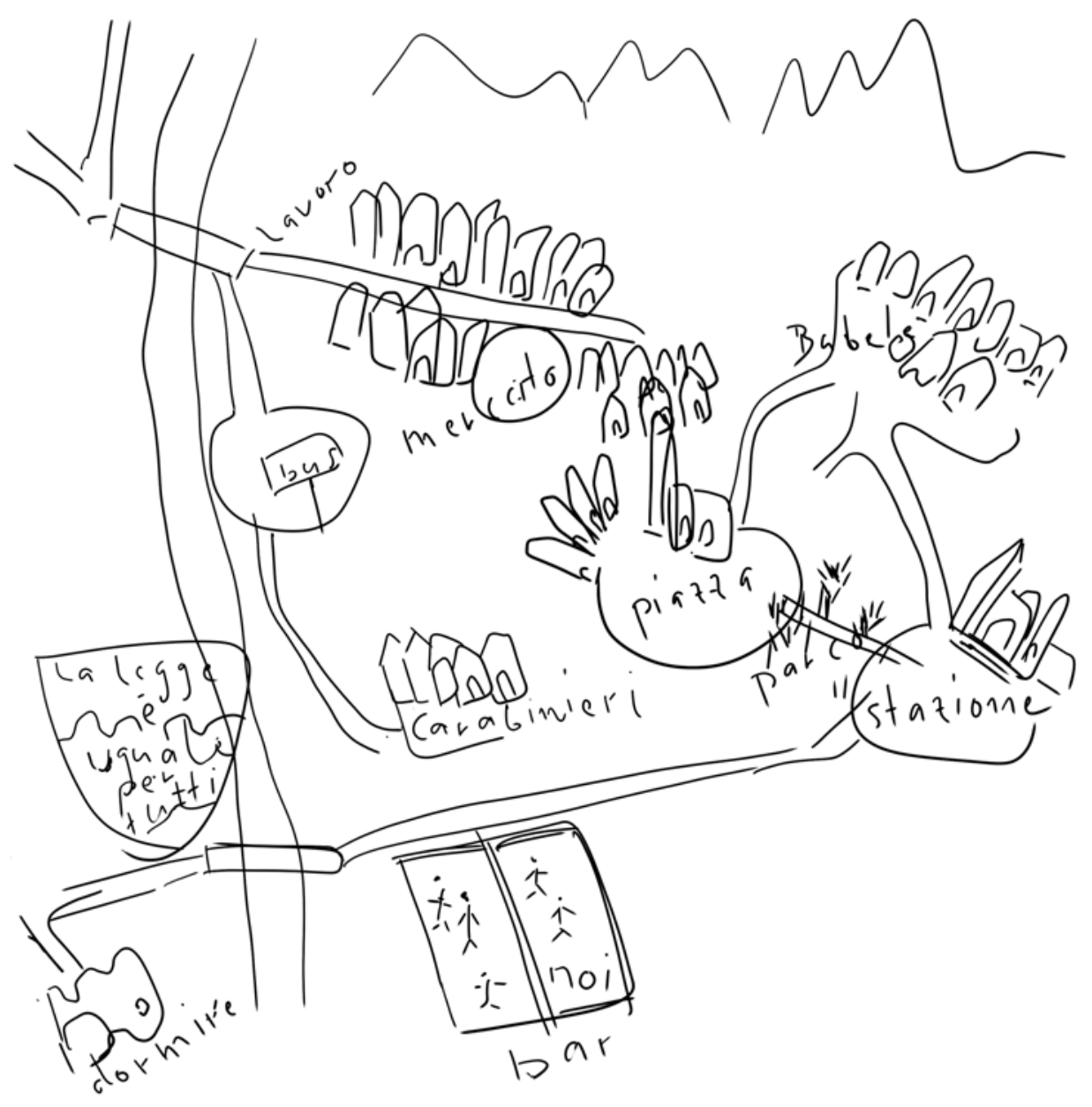

Fig. 7 - Mamadou's

Mobility Map.

Courtesy of the

author. 


\section{When space is limited, people who cannot physically separate themselves, through rituals enter in another measure of time.}

The African village

In Bolzano, as in any other city in the world, Mouride residents inhabit an African village (Scidà, Pollini, 1993). As a result, “Touba-Bolzano" becomes part of a trans-urban nexus connected to Touba. Mobility maps allow the recording, comparison, and analysis of travel activity by different people within the community. They reveal patterns that might otherwise be hidden and highlight all contacts. Unsurprisingly, at least in the first phase of migration, these maps do not differ much from each other because of the strong emphasis placed on pictorial elements of the Mouride archipelago: household, work, and da'ira. Clearly, spatial confinement has a more complex explanation owing to cultural frontiers as well as the autonomous structure of a self-sufficient culture of migration.

To understand how the Mourides use space, we need to look briefly at the distinction between temporal divisions and spatial ones. For instance, synchronic time in the "African village" in Bolzano means that, under crowded conditions, spatial divisions between sacred and secular categories are non-existent: praying, eating, and watching TV all take place in the same rooms at the same time. For "When space is limited, people who cannot physically separate themselves, through rituals enter in another measure of time” (Ebin, 1996). Occupying rooms for a series of different purposes over time makes these separations in time just as effective as spatial divisions.

No physical barrier separates Mouride space from the outside nor is there a distinct spatial arrangement which identifies the space as Mouride. What does distinguish the space is the choreography, the way people move within at specific times (ibid.).

How the African Village really works becomes clearer when an important Mouride sheikh arrives in Bolzano and visits his followers. His presence reveals a more formal order, activating notions of hierarchy and centrality; hence, more attention is paid to separations within the community. The sheikh's room is located in the innermost region of the Mouride village and in this spatial arrangement the holy man lives in the most protected location inside his apartment. 
While the apartment design is purely European, the use of space is similar to a traditional sheikh's house in which an enclosed structure is built around a series of concentric circles or squares with the sheikh in the central, most interior, most protected space (ibid.).

\section{Geographies of trauma}

A focus on topology as a simple arrangement of network elements would disregard a central aspect: trauma. Thus, topology has to be rooted in psychoanalysis. Migrants spatialise their trauma experience by asserting the ways in which material space (where they were physically located during the event) intersects with psychic space (where they remember being). Trauma practices work to translate (topologically) the geopolitics of crisis and displacement into a qualitatively different space of care and security (Blum, Secor, 2014). This place of relocation is in fact a 'safe location', a zone most proximate to danger and yet just beyond risk.

To understand this point better, in particular how trauma works to fold both space and time within migration, we must make a digression into the history of the Muridiyyah. Mouride networks are related to a very early case of deterritorialization. In the 1970s, drought afflicted the Sahel region and turned acres of the Mouride 'peanut basin' into wasteland. Many Mourides working in agriculture turned towards trade, eventually expanding to international commerce, and developed trade circuits stretching from Senegal to the rest of the world.

The Mourides have suffered traumatic experiences - a flood of intolerable stimuli that could be said to have happened out of place or sequence. The trauma is, in a sense, unlocalisable, yet it is nevertheless spatial. It is through 'repetition phenomena' that the spatiality of trauma can be better understood. The Mourides have learned to apply certain elements of their own rural culture to the urban context they now live in. This is the path followed when they set up the da'ira to conquer informal markets in Dakar or San Louis in Senegal.

\section{Anarchitecture as a new home}

What are the spatial, territorial, and material strategies that could secure architecture's role as the most integral cultural technique shaping our lives? Mouride migration steers us towards an architecture that

\section{What are the spatial, territorial, and material strategies that could secure architecture's role as the most integral cultural technique shaping our lives?}




\section{Migration may be conceptualised through the migrant's body as a mutable site for negotiating and articulating the transnational experience of mobility.}

would not only modify the forms of buildings but also their very modes of inhabitation as well as the very nature of their inhabitants. The notion of permanent and uncontrollable change, multiple influences, etc., are fundamental parameters of Mouride practices. Their processual activities aim to initiate transformation and observe change, rather than manipulate space and its inhabitants through decisions regarding form. Migration may be conceptualised through the migrant's body as a mutable site for negotiating and articulating the transnational experience of mobility. While the body constitutes one particular challenge to ideas of physical coherence, all bodies pass through some version of building and un-building. Perhaps this is the point where we must deconstruct both notions: the "migrant in the building" and the "building in the migrant”. Then the counter-architectural project will come to be known as an-architecture attempting to expose existing 'projects'. Gordon Matta-Clark’s 'an-architectural project' not only challenged Le Corbusier's saying: "Everything must hold together, or it will collapse!”, but also emphasised the absence of some bodies (e.g. the disabled and the sick), the suppression or incarceration of others, and spatial segregation. He examined an-architectural 'practices of unmaking' in order to develop a new conception, 'anarchitecture', focused on the body (Halberstam, 2012). Looking at Mouride space-making, Matta-Clark's work can be used as the point where 'embodiment' shifts from a psychoanalytic (topological) to a materialist framework in which corporeality is understood with regard to 'matter' both as a living substance and as social 'mattering' (Wigley, 2018).

From here, one can move on towards the project of 'undoing migration' with the help of architecture. Indeed, Matta-Clark's 'interzones' can be found in the counter-capitalist landscape of 'vertical cities' around Italy. For example, "Hotel House" (Cancellieri, 2007) in Porto Recanati is a seventeen-floor building dating from 1970. It embodies the failure of a Fordist dream of space, safety, and consolidation, and has also registered the decline of the urban periphery from utopian enclave to left-over space. It is closely linked to the internal migration of Mouride people in and around Italy in the early 1990s, when they moved North owing to changed working conditions, ending up into partly overcrowded apartments in rundown 
buildings (Ndiaye, Ndiaye, 2006). Having lost their initial function, these abandoned houses were modified by migrants, who turned them into self-referential systems - an example of how migration folds itself into an existing architectural structure.

However, these residents operate within a context of considerable constraint. They cannot truly appropriate household space. They can transform it to a very limited extent, because the buildings do not belong to them in any legal sense. Hotel House is a huge building that shelters more than 2000 people, mostly families, from 32 countries. Cut off from their surroundings by the police, some migrants built deep wells (as they would have done in Africa) and lift buckets of water up the façade using ropes.

Architecture as we know it must be undone to rebuild itself, as Judith Butler once stated: "We must be undone in order to do ourselves: we must be part of a larger social fabric of existence in order to create who we are” (Butler, 2004).

\section{Conclusion}

Architecture and space are closely intertwined and constantly interact, but their relationship can never take the simple form of a fixed project. Dealing with Mouride territory involves a shift away from order towards a vision of proliferation and confusion, which compels the amalgamating power of architecture to take a new, unexpected path. Migration is a complex issue, whose many facets need to be weighed up.

From refugee camps to slums to housing crises in rich global cities, the message is clear: migration is a topic that architects must understand and respond to.

In this context, architecture is often perceived as a transformation of space - both in the sense of the physical and immaterial reality in which we live. This relationship is one that, as a society, we often have trouble understanding, because we do not acknowledge that environments also have a transformative power over architecture. Indeed, architecture cannot be reduced to an inhabitable building. It is a system: the physical infrastructure of space, intangible connections, and a medium and prerequisite for movement.

\section{Architecture and space are closely intertwined and constantly interact, but their relationship can never take the simple form of a fixed project.}




\section{References}

Appadurai, A. (1995), The Production of Locality, in R. Fardon (ed.), Counterworks. Managing the Diversity of Knowledge, London, Routledge, pp. 204-225.

Balibar, A. (2009), Europe as Borderland, "Society and Space”, n. 27, pp. 190-215.

Barajas, D. (2003), Dispersion. A Study of Global Mobility and the Dynamics of a Fictional Urbanism, Rotterdam, Episode.

Bava, S. (2003), De la "baraka aux affaires": ethos économico-religieux et transnationalité chez les migrants sénégalais mourides, "Revue Européenne des Migrations Internationales”, vol. 19, n. 2, pp. 69-84.

Blum, V., Secor, A. (2014), Mapping Trauma: Topography to Topology, in P. Kingsbury, S. Pile (eds), Psychoanalytic Geographies, Burlington, Ashgate, pp. 103-116.

Butler, J. (2004), Undoing Gender, New York - London, Routledge, pp. 100-101.

Cancellieri, A. (2007), Hotel House. In un palazzo il mondo. Confini sociali e uso quotidiano di uno spazio multietnico, Tesi di laurea, Università degli Studi di Padova.

Clifford, J. (1998), Mixed feelings, in P. Cheah, B. Robbins (eds), Cosmopolitics: Thinking and Feeling Beyond the Nation, Minneapolis, University of Minnesota Press, pp. 362-370.

Ebin, V. (1996), International Networks of Trading Diaspora. The Mourides of Senegal abroad, in P. Antoine, A. B. Diop (eds), La ville à guichets fermés?, Paris, IFAN/ORSTOM 1995, pp. 323-336.

Ebin, V. (1996), Making Room versus Creating Space. The Construction of Spatial Categories by Itinerant Mouride Traders, in B. D. Metcalf (ed.), Making Muslim Space in North America and Europe, Berkeley, University of California Press. Available at: http://ark.cdlib.org/ark:/13030/ft2s2004p0 [Accessed: 20 July 2020].

Glick Schiller, N., Basch, L., Szanton Blanc, C. (eds) (1992), Toward a Transnational Perspective on Migration, New York, Academy of Sciences.

Grillo, R., Riccio, B., Salih, R. (2000), Here or There? Contrasting experiences of transnationalism: Moroccans and Senegalese in Italy, Brighton, CDE Working Paper, University of Sussex.

Halberstam, J. (2020), Unbuilding Gender, “Archithese”, July/ August 2020, pp. 28-33.

Jacques, C. (2016), Struggles for Space. Queering Straight Space. Thinking Towards a Queer Architecture, "Autonomies", October 3. Available at: https://www.thesitemagazine.com/ read/queering-architecture [Accessed: 12 June 2020].

Kaag, M. A. (2008), Mouride Transnational Livelihoods at the Margins of a European Society: The Case of Residence Prealpino, Brescia, Italy, "Journal of Ethnic and Migration Studies", vol. 4, n. 2, pp. 271-285.

Lee, S., Baumeister, R. (eds) (2007), The Domestic and the Foreign in Architecture, Rotterdam, 010 Publishers. 
Miller, D. (1987), Material Culture and Mass Consumption, Oxford, Blackwell.

Morley, D. (2001), Belongings. Place, Space and Identity in a Mediated World, "European Journal of Cultural Studies", n. 4, pp. 425-448.

Ndiaye, D., Ndiaye G. (2006), Creating the Vertical Village: Senegalese Traditions of Immigration and Transnational Cultural Life, in A. Kwadwo Kandu (ed.), The New African Diaspora in North America, Oxford, Lexington Books.

Pries, L. (ed.) (1999), Migration and Transnational Social Spaces, Aldershot, Ashgate.

Salzbrunn, M. (2004), The Occupation of Public Space through Religious and Political Events: How Senegalese Migrants became a Part of Harlem, New York, "Journal of Religion in Africa”, n. 34, pp. 468-492.

Sassen, S. (2004), Local Actors in Global Politics, "Current Sociology”, n. 52, pp. 649-670.

Schmidt di Friedberg, O. (1994), Islam, solidarietà e lavoro. I Mouridei senegalesi in Italia, Torino, Edizione della Fondazione Agnelli.

Scidà, G., Pollini, G. (1993), Stranieri in città: politiche sociali e modelli d'integrazione, Milano, FrancoAngeli.

Sinatti, G. (2006), Space, Place and Belonging. Senegalese Migrants Between Translocal Practices and Diasporic Identities, Milano, Università degli Studi di Milano-Bicocca.

Tarrius, A. (1994), Zirkulationsterritorien von Migranten und städtische Räume, in M. Morodvasic, H. Rudolph (eds), Wanderungsraum Europa. Menschen und Grenzen in Bewegung, Berlin, Edition Sigma, pp. 113-132.

Timera, M. (2014), Migration's Narratives and Troubles: From Anathema to Accolade, “Cahiers d'études africaines”, vol. 1, pp. 213-214.

Wigley, M. (2018), Cutting Matta-Clark: The Anarchitecture Investigation, Zürich, Lars Müller. 